\title{
Porter's Generic Competitive Strategies and its influence on the Competitive Advantage
}

\author{
Bayad Jamal Ali ${ }^{1}$, Govand Anwar ${ }^{2}$ \\ ${ }^{1}$ Business Administration Department, Komar University of Science and Technology, Sulaimani 46001, Kurdistan Region - Iraq \\ ${ }^{2}$ Department of Business Administration, College of Administration and Financial Sciences, Knowledge University, 44001 Erbil, \\ Kurdistan Region, Iraq
}

Received: 03 Apr 2021; Received in revised form: 11 May 2021; Accepted: 24 May 2021; Available online: 06 Jun 2021

\begin{abstract}
The ever-changing competitive business climate poses major hurdles to investment businesses, particularly the banking sector, as well as any other firm in Iraq's Kurdistan area, and business managers have been striving to stay competitive. Porter demonstrated that pursuing a competitive generic strategy can lead to a stronger competitive advantage. The purpose of this research is to determine the effects of Porter's generic strategies on competitive advantage in the investment industry, specifically in the banking sector. Also, which strategy is superior to the others in terms of gaining a competitive advantage in the investing industry? The data in this study was analyzed using a qualitative method. In Erbil, a random sample method was employed to collect data from private banks. The sample size for this study was 128 units, whereas the population was roughly 210 units. According to multiple regression analysis, the researcher discovered that cost leadership has a strong predictive value for competitive advantage (Beta is weight 0.708, p.001), indicating that cost leadership approach will have a direct beneficial impact on competitive advantage. The initial hypothesis was confirmed as a result of these findings. In terms of the second research hypothesis, differentiation strategy has a weak positive influence on competitive advantage (Beta is weight 0.180, p.001), implying that differentiation strategy has a weak positive impact on competitive advantage. The second hypothesis was supported based on these findings, and the third research hypothesis was supported based on these findings: focus strategy has significantly predicted competitive advantage (Beta is weight 0.102, p.001), indicating that focus strategy will have a weak positive impact on competitive advantage.
\end{abstract}

Keywords- Porter's Generic Strategy, Cost Leadership, Differentiation, Focus, Investment, Banking Sector.

\section{INTRODUCTION}

Investment industries have recently experienced a significant boost in demand (Hamza et al. 2021). Investment sectors are projected to continue to be the primary source of the country's economy in the foreseeable future (Ismael et al. 2021). The focus of this research is on banking investment in Iraq's Kurdistan region. In Iraq's Kurdistan Region (Jamal et al. 2021), the banking industry is one of the most significant and rapidly rising. Kurdistan (Sabir et al. 2021), Iraq's Kurdistan, has recently become one of the hottest investment destinations in the world (Saleh et al. 2021).

This article can be downloaded from here: $w w w . i j a e m s . c o m$

C2021 The Author(s). Published by Infogain Publication.

This work is licensed under a Creative Commons Attribution 4.0 License. http://creativecommons.org/licenses/by/4.0/
The banking sector is constantly expanding, and it is becoming more and more appealing for investment every day (Sorguli et al. 2021). This is regarded as one of the most important contributions to a country's economy, and an increasing number of banks are looking to invest in the region. Many banks are in the beginning stages of their operations (Talim, et al. 2021), and the region as a whole is still developing and adjusting to global standards (Top \& Ali, 2021).

Banks are currently in need of a defined strategy and direction. The banks are working hard to achieve the deadlines set by the region's municipal governments and to begin serving customers as soon as feasible (Abdullah et al. 
2021). Bank competition has increased, making it difficult for new potential banks to enter the market (Ahmed et al. 2021). As a result, in today's competitive market, strategies have become an extremely important managerial tool (Akoi et al. 2021). The major direction of the firm is shown by strategic management (Ali \& Anwar, 2021), which comprises organizational goals, formulating plans and policies to achieve these goals, and allocating resources to implement a set of strategies (Ali et al. 2021).

This study focuses on Porters' generic strategy model (Ali et al. 2021), which includes cost leadership strategy, focus strategy, and differentiation strategy (Ali, 2014), to enable banks to get a competitive edge in the market place (Andavar et al. 2020).

\section{Research Objectives}

The primary goal of the study was to determine the impact of Porter's generic tactics on competitive advantage in the investment industry, namely in the banking sector. To achieve this research goal, the study needed to determine the impact of three generic strategies on competitive advantage: first, the impact of cost leadership strategy on competitive advantage, second, the impact of differentiation strategy on competitive advantage, and third, the impact of focus strategy on competitive advantage. Also, which strategy is superior to the others in terms of gaining a competitive advantage in the investing industry?

\section{LITERATURE REVIEW GENERIC STRATEGY}

Strategy, according to (Anwar \& Abd Zebari, 2015), can be defined as "building a strong defense against the five competing factors (Anwar \& Abdullah, 2021). To cope successfully with Porter's five competing forces and so generate a lasting competitive advantage, businesses in the Oil and Gas industries must generate an insecure position through competitive strategy (Anwar \& Balcioglu, 2016).

Despite the fact that a company's strengths and shortcomings may differ from those of its competitors (Anwar \& Climis, 2017), it can only have one of two forms of competitive advantage: low cost or differentiation (Anwar \& Ghafoor,2017). Strategy, according to (Anwar \& Qadir, 2017), is the process of developing an useful and distinct position through a variety of activities (Anwar \& Shukur, 2015). A company must choose between being a differentiator or a cost leader (Anwar \& Surarchith, 2015); it is impossible to achieve both at the same time (Anwar, 2016). The two types of competitive advantage (Anwar, 2017), together with the range of competitive actions that the company tries to achieve them, result in three generic

This article can be downloaded from here: www.ijaems.com strategies that surpass competitors (Anwar, K., \& Louis, 2017).

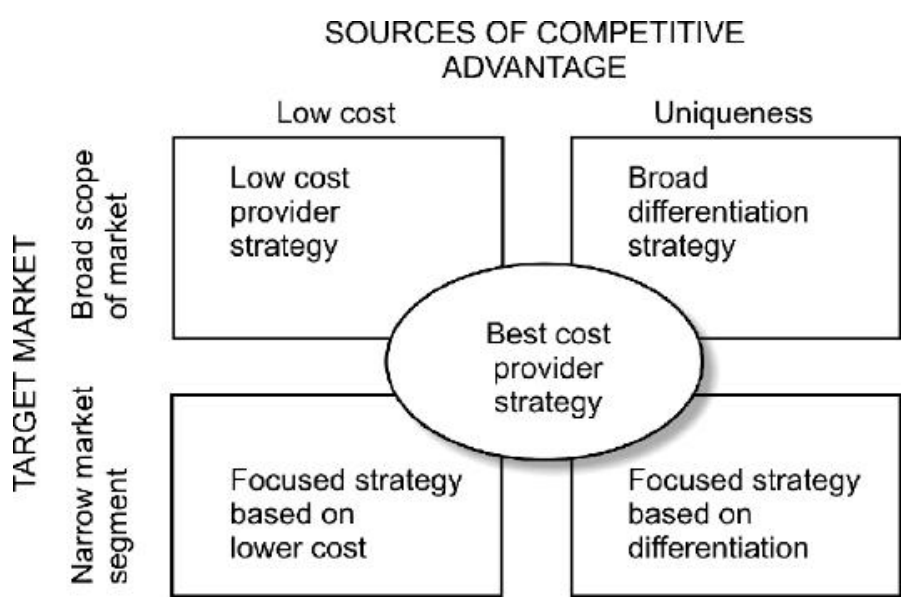

Fig.1: Generic competitive strategy, Porter (1980)

As seen in figure (1) the generic competitive strategies. Three kinds of strategies are considered as generic (Aziz et al. 2021), the reason is because all three strategies apply into different types of businesses (Demir et al. 2020). Every business should apply only one of those generic strategies, in case if a business fails with all three strategies this means that the business has no advantages (Faraj et al. 2021). Each of the generic strategies involves a different route to competitive advantage (Hameed \& Anwar, 2018). Cost leadership strategy connects the business to be the lowest cost seller or producer within the industry with the same potential profit (Hamza et al. 2021). Differentiation strategy makes the business to produce or sell unique products or services (Ismael et al. 2021). Focus strategy that makes the business to efficiently serve a specific customer or market segment (Jamal et al. 2021).

Cost Leadership Strategy: This strategy concentrates on low cost in terms of businesses' activities and could functionalized as low pricing, low input (Sabir et al. 2021), experience, the design of the products, economies of scale and the design of the process (Saleh et al. 2021). Concerning low pricing is the process of creating similar product in terms of features to competitors but in lower price (Sorguli et al. 2021). While low input including having inexpensive labour and location is closer to the raw materials and storage (Talim, et al. 2021). In terms of experience, more experience will have positive impact on effectiveness and efficiency (Top \& Ali, 2021). Economies of scale needs larger scale operations and the design of the process/ the design of the product effect effectively through creating goods from lower price (Abdullah et al. 2021).

Differentiation strategy: This sort of strategy concentrates on product or service uniqueness, which provides consumer 
with valuable product (Ahmed et al. 2021). The differentiation can be done by special features, brand name/image, technology, supplier or distributors, marketing message or advertising (Akoi et al. 2021).

Focus strategy: This strategy concentrates on specific target or market segment (Ali \& Anwar, 2021). In case of that differentiation strategy failed or cost leadership strategy failed also, then organization can adapt focus strategy (Ali et al. 2021). Also this strategy can be implementing for time limitation product or services (Ali et al. 2021).

\section{Conceptual Review}

Figure (2) shows the conceptual framework of this study. The researcher identified two variables in below research model, competitive advantage as dependent vairable on the other hand, generic strategies ( focus, differentiation and cost leadership) as independent variables. The framework is according to the research hypothesis that adoption of Perter's generc strategicies in order to gain competitive advantage in the marketplace.

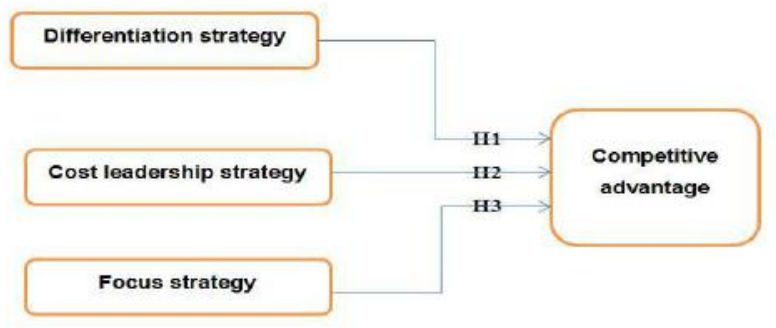

Fig.2: Research model, created by the researcher

Research hypothesis:

H1: There is a positive impact of differentiation strategy on competitive advantage

$\mathrm{H} 2$ : There is a positive impact of cost leadership strategy on competitive advantage
H3: There is a positive impact of focus strategy on competitive advantage

\section{METHODOLOGY}

This section introduces the design of the study, sampling size, target population and instruments.

\section{Design of the study}

Qualitative method used in this study to analyze data. The researcher used a questionnaire and distributed in four banks in Erbil city. The questionnaire consisted of two sections; first section was demographic questions (participants' background information). The demographic questions consisted of participant's age, gender, level of education and year(s) of experience. The second section of the questionnaire was questions regarding of Porter's three generic strategies (Cost leadership strategy, differentiation strategy and focus strategy). In terms of differentiation strategy, the researcher asked 6 questions, focus strategy 13 questions, cost leadership 8 questions and competitive advantage 6 questions.

\section{Sampling size and target population}

The researcher used random sampling method in order to gather data from private banks in Erbil city. The population of this study was approximately 210 units. The target population was 142 units. The researcher distrusted 150 questionnaires at four different private banks, from 150 questionnaires; the researcher was able to gather 128 questionnaires that have been completed properly. Accordingly, the sample size of this study was 128 units.

\section{Instruments}

The questionnaire was designed in a multiple choise quesirons. The respondents were asked to mark each question on five scales ranging from strongly disagree to strongly agree. The questionnaire was adapted from two differnt soruces (He, et al. 2012) and (Kinyuira 2014).

\section{DATA ANALYSIS}

Table.1: Demographic analysis

\begin{tabular}{|l|l|l|}
\hline Gender & Frequency & Percent \\
\hline Male & 84 & 65.6 \\
\hline Female & 44 & 34.4 \\
\hline Age & & Prequency \\
\hline
\end{tabular}

This article can be downloaded from here: www.ijaems.com 


\begin{tabular}{|c|c|c|}
\hline $20-29$ & 42 & 32.8 \\
\hline 30-39 & 51 & 39.8 \\
\hline $40-49$ & 22 & 17.2 \\
\hline $50-59$ & 12 & 9.4 \\
\hline 60 and above & 1 & 8 \\
\hline Education & Frequency & Percent \\
\hline Bachelor & 121 & 94.5 \\
\hline master & 5 & 3.9 \\
\hline $\mathrm{PhD}$ & 2 & 1.6 \\
\hline Experience(s) & Frequency & Percent \\
\hline Less than a year & 1 & .8 \\
\hline $1-2$ & 23 & 18 \\
\hline $3-4$ & 24 & 18.8 \\
\hline $5-6$ & 33 & 25.8 \\
\hline $7-8$ & 18 & 14.1 \\
\hline $9-10$ & 17 & 13.3 \\
\hline 11 and over & 12 & 9.4 \\
\hline
\end{tabular}

Table (1) explain demographic analysis for respondents participated in this study. As seen in the above table 84 male participants participated in this study and 44 participants participated in this study. 42 respondents fall into a group of 20-29 years old, 51 respondents fall into a group of 3039 years old, 22 respondents fall into a group of 40-49 years This article can be downloaded from here: www.ijaems.com old, 12 respondents fall into a group of 50-59 years old and only one participant fall intro group of 60 years old and above. 121 participants had bachelor degree, 5 participants had Masters degree and 2 participants had PhD degree. Only one participant had less than one year experience, 23 participants had 1-2 years of experiences, 24 participants 
had 3-4 years of expriences, 33 participants had 5-6 years of experiencs, 18 participants had 7-8 years of experiences,
17 participants had 9-10 years of experiences and 12 participants had 11 years of experiences and over.

Table 2 Reliability test

\begin{tabular}{|l|l|l|}
\hline Variables & Cronbach's Alpha & Number of items \\
\hline Differentiation & .776 & 6 \\
\hline Focus & .960 & 13 \\
\hline Cost leadership & .975 & 8 \\
\hline Competitive advantage & .823 & 6 \\
\hline
\end{tabular}

Table (2), shows reliability analysis for three independent variables and competitive advantage as dependent variable, According to the reliability analysis, the researcher found out Cronbach's Alpha for differentiation factor =.776 for which is greater than .7 this means that items of differentiation factor were reliable for this study, Cronbach's Alpha for focus factor =. 960 for which is greater than .7 this means that items of focus factor were reliable for this study, Cronbach's Alpha for cost leadership factor $=.975$ for which is greater than .7 this means that items of cost leadership factor were reliable for this study and Cronbach's Alpha for competitive advantage factor = .823 for which is greater than .7 this means that items of competitive advantage factor were reliable for this study.

Table.3: Correlation analysis

\begin{tabular}{|c|c|c|c|c|}
\hline \multicolumn{5}{|c|}{ Correlations } \\
\hline & & Costleadersip & Differentiation & Focus \\
\hline \multirow[t]{4}{*}{ Costleadersip } & Pearson & 1 & $.564^{* 8}$ & $.470^{* 8}$ \\
\hline & Correlation & & & \\
\hline & Sig. (2-tailed) & & .000 & .000 \\
\hline & $\mathrm{N}$ & 128 & 128 & 128 \\
\hline \multirow[t]{4}{*}{ Differentiation } & Pearson & $.564^{88}$ & 1 & $.544^{88}$ \\
\hline & Correlation & & & \\
\hline & Sig. (2-tailed) & .000 & & .000 \\
\hline & $\mathrm{N}$ & 128 & 128 & 128 \\
\hline \multirow[t]{4}{*}{ Focus } & Pearson & $.470^{88}$ & $.544^{88}$ & 1 \\
\hline & Correlation & & & \\
\hline & Sig. (2-tailed) & .000 & .000 & \\
\hline & $\mathrm{N}$ & 128 & 128 & 128 \\
\hline \multirow{4}{*}{$\begin{array}{l}\text { Competitive } \\
\text { advantage }\end{array}$} & Pearson & $.627^{88}$ & $.865^{88}$ & $.572^{* 8}$ \\
\hline & Correlation & & & \\
\hline & Sig. (2-tailed) & .000 & .000 & .000 \\
\hline & $\mathrm{N}$ & 128 & 128 & 128 \\
\hline
\end{tabular}

Correlations analysis presents the values of the identified correlation tests; Table (3) shows the correlations between the scales using person correlation. Correlation analysis is determined the strength of relationship between variables. The researcher correlated Cost leadership strategy, differentiation strategy and focus strategy as independent variables with competitive advantage as dependent variable. According to correlation test, the researcher found out that cost leadership strategy has significant correlation $\left(r=.627^{* *}\right.$, $\mathrm{p}<0.01$ ) with competitive advantage. Concerning the strength of the linear relationship is moderately strong between cost leadership strategy and competitive advantage, also differentiation strategy has significant correlation $\left(r=.865^{* *}, \mathrm{p}<0.01\right)$ with competitive advantage. Concerning the strength of the linear relationship is moderately strong between focus strategy and competitive

This article can be downloaded from here: www.ijaems.com 
advantage, and focus strategy has significant correlation $\left(r=.572^{* *}, p<0.01\right)$ with competitive advantage.

\section{Regression analysis}

Table.4: Model summary

\begin{tabular}{|l|c|c|c|c|}
\hline \multicolumn{5}{|c|}{ Model Summary } \\
\hline Model & $\mathrm{R}$ & 'R Square & Adjusted R Square & Std. Error of the Estimate \\
\hline 1 & $.886^{\mathrm{a}}$ & .784 & .779 & .360 \\
\hline
\end{tabular}

Regression analysis is analyzing relationships among factors. $\mathrm{Y}=\mathrm{f}(\mathrm{x} 1, \mathrm{x} 2 \ldots \mathrm{Xc})$. Regression analysis is to estimate the how $\mathrm{Y}$ will influence and change $\mathrm{X}$ and predict. In this research cost leadership strategy, differentiation strategy and focus strategy as independent variables and competitive advantage is dependent. The competitive advantage's overall difference could be measured by its variance. The differences are measured as the sum of the square between participant's forecasted competitive advantage values and the total mean divided by the number of participants. After division it will clarify variance by the total variance of competitive advantage, the researcher found out the amount or the number of total difference or variance that is accounted based on regression calculation. The number should vary between $0-1$ and is symbolized by $\mathrm{R}$ Square. Table (4) shows the value of $\mathrm{R}$ square $=.784$ this indicates that $78 \%$ of total variance has been explained.

Table.5: ANOVA

\begin{tabular}{|l|l|r|r|r|r|c|}
\hline \multicolumn{7}{|l|}{ ANOVA $^{\mathbf{a}}$} \\
\hline \multicolumn{2}{|l|}{ Model } & \multicolumn{1}{|c|}{ Sum of Squares } & \multicolumn{1}{c|}{ df } & Mean Square & F & Sig. \\
\hline \multirow{3}{*}{1} & Regression & 58.488 & 3 & 19.496 & 150.351 & $.000^{\mathrm{b}}$ \\
\cline { 2 - 7 } & Residual & 16.079 & 124 & .130 & & \\
\cline { 2 - 7 } & Total & 74.568 & 127 & & & \\
\hline \multicolumn{2}{|l|}{ a. Dependent Variable: competitiveadvantage } \\
\hline
\end{tabular}

Table.6: Coefficients

\begin{tabular}{|c|c|c|c|c|c|c|}
\hline & \multirow[t]{2}{*}{$\overline{\text { Model }}$} & \multicolumn{2}{|c|}{ Unstandardized Coefficients } & \multirow{2}{*}{$\begin{array}{c}\begin{array}{c}\text { Standardized } \\
\text { Coefficients }\end{array} \\
\text { Beta }\end{array}$} & \multirow[t]{2}{*}{$\mathrm{t}$} & \multirow[t]{2}{*}{ Sig. } \\
\hline & & B & Std. Error & & & \\
\hline \multirow{4}{*}{1} & (Constant) & -.535 & .436 & & -1.228 & .225 \\
\hline & cost leadership & .911 & .085 & .801 & 10.715 & .000 \\
\hline & Differentiation & .280 & .171 & .250 & 1.639 & .108 \\
\hline & Focus & .088 & .156 & .087 & .564 & .575 \\
\hline
\end{tabular}

Dependent Variable: Competitive Advantage

Table (6) explains the result of research hypotheses, in terms of first research hypothesis, cost leadership has significantly predicted competitive advantage (Beta is weight $0.801, \mathrm{p}<.001)$ this indicates that cost leadership strategy will have a direct positive impact on competitive advantage based on this results the first hypotheses was supported. In terms of second research hypothesis, differentiation strategy has significantly predicted

This article can be downloaded from here: $w w w . i j a e m s . c o m$ competitive advantage (Beta is weight $0.250, \mathrm{p}<.001$ ) this indicates that differnation strategy will have a weak positive impact on competitive advantage based on this results the second hypotheses was supported, and in terms of third research hypothesis, focus strategy has significantly predicted competitive advantage (Beta is weight 0.087 , $\mathrm{p}<.001)$ this indicates that focus strategy will have a weak 
positive impact on competitive advantage based on this results the third hypotheses was supported.

\section{CONCLUSION}

Generally most organizations have different strategies to to gain and win competitive advantage. Micheal ported developed generic strategies such us cost leadership, differentation and focus strategy in order to enable organization to gain competitve advantage. However, previous researches have explained that there is an association between porter's generis strategies and competitive advantage. The current research evidence demonstrated the positive association between porter's generic stratgegies (cost leadership, differentation and focus) with firm's competitive advantage. The finding of this research was based on three different strategies and its relation with competitive advantage, the first factor is cost leadership, the correlation of cost leadership strategy as independent variable with competitive as dependent variable. According to correlation test, the researcher found out that cost leadership strategy has significant correlation $\left(\mathrm{r}=.627^{* *}, \mathrm{p}<0.01\right)$ with competitive advantage. Concerning the strength of the linear relationship is moderately strong between cost leadership strategy and competitive advantage. The result of first research hypothesis, cost leadership has significantly predicted competitive advantage (Beta is weight $0.708, \mathrm{p}<.001$ ) this indicates that cost leadership strategy will have a direct positive impact on competitive advantage based on this results the first hypotheses was supported. In terms of differntation strategy, the researcher found out that differntation strategy has significant correlation $\left(r=.516^{* *}, \mathrm{p}<0.01\right)$ with competitive advantage. Concerning the strength of the linear relationship is moderately strong between differntation strategy and competitieve advantage. The result of second hypotheses, differentiation strategy has significantly predicted competitive advantage (Beta is weight $0.180, \mathrm{p}<.001)$ this indicates that differnation strategy will have a weak positive impact on competitive advantage based on this results the second hypotheses was supported. In terms of focus strategy the researcher found out that focus strategy has significantly predicted competitive advantage (Beta is weight $0.102, \mathrm{p}<.001$ ) this indicates that focus strategy will have a weak positive impact on competitive advantage based on this results the third hypotheses was supported. According to the multiple regression analysis, the researcher found out that the highest value was for cost leadership strategy, accordingly it concluded that a successful investment company should adapt cost leadership strategy in order to be able to gain competitive advantage in the marketplace.

\section{REFERENCES}

[1] Top, C., \& Ali, B. J. (2021). Customer satisfaction in online meeting platforms: Impact of efficiency, fulfillment, system availability, and privacy. Amazonia Investiga, 10(38), 7081. https://doi.org/10.34069/AI/2021.38.02.7

[2] Demir, A., Maroof, L., Sabbah Khan, N.U. and Ali, B.J. (2020), "The role of E-service quality in shaping online meeting platforms: a case study from higher education sector", Journal of Applied Research in Higher Education. https://doi.org/10.1108/JARHE-08-2020-0253

[3] Ali, B, J. (2021). Impact of consumer animosity, boycott participation, boycott motivation, and product judgment on purchase readiness or aversion of Kurdish consumers in Iraq. Journal of Consumers Affaires; 1-20. https://doi.org/10.1111/joca.12350

[4] Ali, B, J. (2020). Impact of COVID-19 on consumer buying behavior toward online shopping in Iraq. Economic studies journal. 18(42): 267-280. Retrieved from https://www.asjp.cerist.dz/en/article/134070

[5] Ali, B.J. (2021) Assessing (The impact) of advertisement on customer decision making: Evidence from an educational institution. Afak for sciences journal, 6(1): 425-439. Retrieved from https://www.asjp.cerist.dz/en/article/141056

[6] Ali, B.J. (2021) Consumer attitudes towards healthy and organic food in the Kurdistan region of Iraq. Management Science Letters. 11: 1-8. DOI: 10.5267/j.msl.2021.2.015

[7] Andavar, V., Ali, B.J., and Ali, S.A. (2020) Rainwater for Water Scarcity Management: An Experience of Woldia University (Ethiopia). Journal of Business, Economics and Environmental Studies, 10-(4): 29-34. DOI: 10.13106/jbees.2020.vol10.no4.29

[8] Faraj, K. M., Faeq, D. K., Abdulla, D. F., Ali, B. J., \& Sadq, Z. M. (2021). Total Quality Management And Hotel Employee Creative Performance: The Mediation Role Of Job Embeddedment. Journal of Contemporary Issues in Business and Government, 27(1), 3838-3855. http://dx.doi.org/10.47750/cibg.2021.27.01.001

[9] Ali, B. J. (2016). Iraq Stock Market and its Role in the Economy. Retrieved from https://www.amazon.com/IraqStock-Market-Role-Economy/dp/3659634271

[10] Ali, B. J. (2014). Brand Building in the Consumer Electronics Industry in Iraq. Retrieved from https://www.amazon.com/Brand-Building-ConsumerElectronics-Industry/dp/6200248699

[11] Ali, B. J., \& Anwar, G. (2021). Factors Influencing the Citizens' Acceptance of Electronic Government. International Journal of Engineering, Business and Management, 5(1), 48-60. https://doi.org/10.22161/ijebm.5.1.5

[12] Saleh, P. F., Ali, B. J., Akoi, S., Najmalddin, B., Ali, R. S., \& Anwar, G. (2021). Factors affecting the Success of Female Entrepreneurs in Kurdistan. International journal of Engineering, Business and Management (IJEBM), 5.

[13] Ali, B. J., \& Anwar, G. (2021). The Effect of Marketing Culture Aspects of Healthcare Care on Marketing Creativity. International Journal of English Literature and Social Sciences, 6(2), 171-182. https://doi.org/10.22161/ijels.62.25 
[14] Ali, B. J., \& Anwar, G. (2021). An Empirical Study of Employees' Motivation and its Influence Job Satisfaction. International Journal of Engineering, Business and Management, $\quad 5(2), \quad 21-30$. https://doi.org/10.22161/ijebm.5.2.3

[15] Ali, B. J., Saleh, P. F., Akoi, S., Abdulrahman, A. A., Muhamed, A. S., Noori, H. N., \& Anwar, G. (2021, May). Impact of Service Quality on the Customer Satisfaction: Case study at Online Meeting Platforms. In Ali, BJ, Saleh, Akoi, S., Abdulrahman, AA, Muhamed, AS, Noori, HN, Anwar, G.(2021). Impact of Service Quality on the Customer Satisfaction: Case study at Online Meeting Platforms. International journal of Engineering, Business and Management (Vol. 5, No. 2, pp. 65-77).

[16] Ali, B. J., \& Anwar, G. (2021). The balanced scorecard's evolution as a strategic mechanism at banking sectors. International Journal of English Literature and Social Sciences, 6(1), 471-478. https://doi.org/10.22161/ijels.61.63

[17] Anwar, G., \& Abdullah, N. N. (2021). Inspiring future entrepreneurs: The effect of experiential learning on the entrepreneurial intention at higher education. International Journal of English Literature and Social Sciences, 6.

[18] Ali, B. J., \& Anwar, G. (2021). Measuring competitive intelligence Network and its role on Business Performance. International Journal of English Literature and Social Sciences, 6(2), 329-345. https://dx.doi.org/10.22161/ijels.62.50

[19] Anwar, G., \& Abdullah, N. N. (2021). The impact of Human resource management practice on Organizational performance. International journal of Engineering, Business and Management (IJEBM), 5.

[20] Abdullah, N. N., \& Anwar, G. (2021). An Empirical Analysis of Natural Gas as an Alternative Fuel for Internal Transportation. International Journal of English Literature and Social Sciences, 6(1).

[21] Ali, B. J., \& Anwar, G. (2021). A study of knowledge management alignment with production management: A study of carpet manufacture in Kurdistan region of Iraq. International Journal of English Literature and Social Sciences, 6(2), 346-360. https://dx.doi.org/10.22161/ijels.62.51

[22] Ali, B. J., \& Anwar, G. (2021). The mediation role of change management in employee development. International Journal of English Literature and Social Sciences, 6(2), 361374. https://dx.doi.org/10.22161/ijels.62.52

[23] Anwar, K., \& Louis, R. (2017). Factors Affecting Students' Anxiety in Language Learning: A Study of Private Universities in Erbil, Kurdistan. International Journal of Social Sciences \& Educational Studies, 4(3), 160.

[24] Ali, B. J., \& Anwar, G. (2021). Business strategy: The influence of Strategic Competitiveness on competitive advantage. International Journal of Electrical, Electronics and Computers, 6(2), 1-10. https://dx.doi.org/10.22161/eec.62.1

[25] Anwar, K. (2017). Leading Construction Project Teams: The Effectiveness of Transformational Leadership in Dynamic Work Environments in Kurdistan. International Journal of
Advanced Engineering, Management and Science, 3(10), 239925.

[26] Ali, B. J., \& Anwar, G. (2021). Strategic leadership effectiveness and its influence on organizational effectiveness. International Journal of Electrical, Electronics and Computers, 6(2), 11-24. https://dx.doi.org/10.22161/eec.62.2

[27] Anwar, K., \& Qadir, G. H. (2017). A Study of the Relationship between Work Engagement and Job Satisfaction in Private Companies in Kurdistan. International Journal of Advanced Engineering, Management and Science, 3(12), 239944.

[28] Ali, B. J., \& Anwar, G. (2021). Intellectual capital: A modern model to measure the value creation in a business. International journal of Engineering, Business and Management, 5(2), 31-43. https://dx.doi.org/10.22161/ijebm.5.2.4

[29] Ali, B. J., \& Anwar, G. (2021). Marketing Strategy: Pricing strategies and its influence on consumer purchasing decision. International journal of Rural Development, Environment and Health Research, 5(2), 26-39. https://dx.doi.org/10.22161/ijreh.5.2.4

[30] Anwar, K. (2017). Factors Affecting Stock Exchange Investment In Kurdistan. The International Journal of Accounting and Business Society, 25(1), 32-37.

[31] Ali, B. J., \& Anwar, G. (2021). Organization citizenship behaviour as a determining Factor in Business outcome. International journal of Rural Development, Environment and Health Research, 5(2), 17-25. https://dx.doi.org/10.22161/ijreh.5.2.3

[32] Anwar, K., \& Climis, R. (2017). Analyzing the relationship between types of advertisement and customer choice: a study of retailer stores in erbil. The International Journal of Accounting and Business Society, 25(2), 43-52.

[33] Talim, S.R., Ali, B.J., Top, C. (2021). Elaborating the Antecedents of Purchase Intentions in Second-Hand Car Industry: Case Study in Kurdistan Region of Iraq. Journal of Contemporary Issues in Business and Government, 27(3), 1526-1547. http://dx.doi.org/10.47750/cibg.2021.27.03.204

[34] Anwar, K., \& Ghafoor, C. (2017). Knowledge management and organizational performance: A study of private universities in Kurdistan. International Journal of Social Sciences \& Educational Studies, 4(2), 53.

[35] Ali, B. J., Saleh, Akoi, S., Abdulrahman, A. A., Muhamed, A. S., Noori, H. N., Anwar, G. (2021). Impact of Service Quality on the Customer Satisfaction: Case study at Online Meeting Platforms. International journal of Engineering, Business and Management, 5(2), 65-77. https://dx.doi.org/10.22161/ijebm.5.2.6

[36] Hameed, A. A., \& Anwar, K. (2018). Analyzing the Relationship between Intellectual Capital and Organizational Performance: A Study of Selected Private Banks in Kurdistan. International Journal of Social Sciences \& Educational Studies, 4(4), 39.

[37] Jamal Ali, B., Akoi, S., Fadel Saleh, P., \& Sardar, zhilwan. (2021). Factors Shaping Customer Satisfaction with Residential Flats: Evidence from Sulaymaniyah City. Black 
Sea Journal of Management and Marketing, 2(2), 1-12. https://doi.org/10.47299/bsjmm.v2i2.69

[38] Akoi, S., Jamal Ali, B., Fadel Saleh, P., Najmalddin, B., Sabah Mustafa, R., Rzgar Abdulmajid, M., \& Rebwar Hama, A. (2021). Elaborating the Characteristics that Affect Buyers in Online Shopping: The Case of Generation Z Girls in Kurdistan Region of Iraq. Black Sea Journal of Management $\begin{array}{llll}\text { and } & \text { Marketing, } & 2(2), & 42\end{array}$ https://doi.org/10.47299/bsjmm.v2i2.74

[39] Anwar, K. (2017). The Role of Effective Leadership in Crisis Management: Study of Private Companies in Kurdistan. Qalaai Zanist Scientific Journal, 2(4), 326-338.

[40] Ahmed, S. Y., Ali, B. J., Top, C. (2021). Understanding the Impact of Trust, Perceived Risk, and Perceived Technology on the Online Shopping Intentions: Case Study in Kurdistan Region of Iraq. Journal of Contemporary Issues in Business and Government, 27(3), 2136-2153. http://dx.doi.org/10.47750/cibg.2021.27.03.264

[41] Anwar, K., \& Balcioglu, H. (2016). The relationship between transformational leadership characteristics and effectiveness: A case study of construction companies in Erbil. International Journal of Science Technology and Management, 5(2), 250-256.

[42] Sabir, B. Y., Othman, B .J., Gardi, B., Ismael, N. B., Hamza, P. A., Sorguli, S., Aziz, H. M., Ahmed, S. A., Ali, B. J., Anwar, G. (2021). Administrative Decentralization: The Transfer of Competency from The Ministry of Education to General Directorates. International Journal of Rural Development, Environment and Health Research, 5(3), 113. https://doi.org/10.22161/ijreh.5.3.1

[43] Abdullah, M. S., Toycan, M., \& Anwar, K. (2017). The cost readiness of implementing e-learning. CUSTOS E AGRONEGOCIO ON LINE, 13(2), 156-175.

[44] Ali, B. J., Anwar, G., Gardi, B., Othman, B. J., Aziz, H. M., Ahmed, S. A., Hamza, P. A., Ismael, N. B., Sorguli, S., Sabir, B. Y. (2021). Business Communication Strategies: Analysis of Internal Communication Processes. Journal of Humanities and Education Development, 3(3), 16-38. https://doi.org/10.22161/jhed.3.3.4

[45] Anwar, K. (2016). Comparison between cost leadership and differentiation strategy in agricultural businesses. Custos $E$ Agronegocio on Line, 12(2), 212-231.

[46] Ali, B. J., Gardi, B., Othman, B. J., Ismael, N. B., Sorguli, S., Sabir, B. Y., Ahmed, S. A., Hamza, P. A., Aziz, H. M., Anwar, G. (2021). Educational system: The policy of Educational system in Kurdistan Region in public Kindergarten. International Journal of English Literature and Social Sciences, 6(3), 062-071. https://doi.org/10.22161/ijels.63.10

[47] Anwar, K. (2017). Analyzing the conceptual model of service quality and its relationship with guests'satisfaction: a study of hotels in erbil. The International Journal of Accounting and Business Society, 25(2), 1-16.

[48] Aziz, H. M., Othman, B. J., Gardi, B., Ahmed, S. A., Sabir, B. Y., Ismael, N. B., Hamza, P. A., Sorguli, S., Ali, B. J., Anwar, G. (2021). Employee Commitment: The Relationship between Employee Commitment And Job Satisfaction. Journal of Humanities and Education
Development,

$3(3)$,

https://doi.org/10.22161/jhed.3.3.6

[49] Anwar, G., \& Shukur, I. (2015). The Impact of Service Quality Dimensions on Students' Satisfaction. International Journal of Social Sciences \& Educational Studies, 76.

[50] Ali, B. J., Gardi, B., Othman, B. J., Ahmed, S. A., Ismael, N. B., Hamza, P. A., Aziz, H. M., Sabir, B. Y., Anwar, G. (2021). Hotel Service Quality: The Impact of Service Quality on Customer Satisfaction in Hospitality. International Journal of Engineering, Business and Management, 5(3), 14-28. https://doi.org/10.22161/ijebm.5.3.2

[51] Anwar, G., \& Surarchith, N. K. (2015). Factors Affecting Shoppers' Behavior in Erbil, Kurdistan-Iraq. International Journal of Social Sciences \& Educational Studies, 1(4), 10.

[52] Sorguli, S., Gardi, B., Othman, B.J., Aziz, H. M., Ahmed, S. A., Sabir, B. Y., Ismael, N. B., Hamza, P. A., Ali, B. J., Anwar, G. (2021) Innovation: Knowledge Management in the Innovating Industries, 6(3), 10-23. https://dx.doi.org/10.22161/eec.63.2

[53] Anwar, G., \& Abd Zebari, B. (2015). The Relationship between Employee Engagement and Corporate Social Responsibility: A Case Study of Car Dealership in Erbil, Kurdistan. International Journal of Social Sciences \& Educational Studies, 2(2), 45.

[54] Hamza, P. A., Othman, B. J., Gardi, B., Sorguli, S., Aziz, H. M., Ahmed, S. A., Sabir, B. Y., Ismael, N. B., Ali, B. J., Anwar, G. (2021). Recruitment and Selection: The Relationship between Recruitment and Selection with Organizational Performance. International Journal of Engineering, Business and Management, 5(3), 1-13. https://doi.org/10.22161/ijebm.5.3.1

[55] Anwar, G., \& Shukur, I. (2015). the impact of recruitment and selection on job satisfaction: Evidence from private school in Erbil. International Journal of Social Sciences \& Educational Studies, 1(3), 4-13.

[56] Ali, B. J., Gardi, B., Othman, B. J., Sabir, B. Y., Sorguli, S., Ismael, N. B., Hamza, P.A., Aziz, H. M., Ahmed, A. A., Anwar, G. (2021). The Role of Shopping Malls on Kurdistan Regional Government's Economy. Journal of Humanities and Education Development, 3(3), 39-53. https://doi.org/10.22161/jhed.3.3.5

[57] Anwar, G., \& Shukur, I. (2015). Job satisfaction and employee turnover intention: A case study of private hospital in Erbil. International Journal of Social Sciences \& Educational Studies, 2(1), 73.

[58] Ahmed, S. A., Othman, B. J., Gardi, B., Sabir, B. Y., Ismael, N. B., Hamza, P. A., Sorguli, S., Aziz, H. M., Ali, B. J., Anwar, G. (2021). Students' Attitudes towards Learning English in the Kurdistan region of Iraq. International Journal of English Literature and Social Sciences, 6(3), 072-087. https://doi.org/10.22161/ijels.63.11

[59] Anwar, G., \& Shukur, I. (2015). The Impact of Training and Development on Job Satisfaction: A Case Study of Private Banks in Erbil. International Journal of Social Sciences \& Educational Studies, 2(1), 65.

[60] Ismael, N. B., Othman, B. J., Gardi, B., Hamza, P. A., Sorguli, S., Aziz, H. M., Ahmed, S. A., Sabir, B. Y., Ali, B. 
J., Anwar, G. (2021). The Role of Training and Development on Organizational effectiveness. International Journal of Engineering, Business and Management, 5(3), 15-24. https://doi.org/10.22161/ijebm.5.3.3 